\title{
Medium-Long-Term Radiographic and Clinical Outcomes after Surgical Treatment of Intra-Articular Tibial Pilon Fractures by Three Different Techniques
}

\author{
Carlo Biz $\mathbb{D}^{1},{ }^{1}$ Andrea Angelini $\left(\mathbb{D},{ }^{1}\right.$ Marco Zamperetti, ${ }^{1}$ Filippo Marzotto, ${ }^{2}$ \\ Silvano Pierluigi Sperotto, ${ }^{1}$ Diego Carniel, ${ }^{1}$ Claudio Iacobellis, ${ }^{1}$ and Pietro Ruggieri ${ }^{1}$ \\ ${ }^{1}$ Orthopaedic and Traumatology Clinic, Department of Surgery, Oncology and Gastroenterology DiSCOG, University of Padua, \\ Via Giustiniani 2, 35128 Padova, Italy \\ ${ }^{2}$ Department of Molecular Medicine (DMM), University of Padua, Via Gabelli 63, 35121 Padova, Italy \\ Correspondence should be addressed to Carlo Biz; carlo.biz@unipd.it
}

Received 8 October 2017; Revised 11 January 2018; Accepted 4 February 2018; Published 1 March 2018

Academic Editor: Nikolaos K. Kanakaris

Copyright (C) 2018 Carlo Biz et al. This is an open access article distributed under the Creative Commons Attribution License, which permits unrestricted use, distribution, and reproduction in any medium, provided the original work is properly cited.

\begin{abstract}
Introduction. The goal of this retrospective, observational, case series study was to evaluate the medium-long-term clinical and radiographic results of the three most common surgical osteosynthesis techniques used for the treatment of articular tibial pilon fractures: ORIF, MIPO, and EF. Materials and Methods. A consecutive series of patients with articular pilon fractures who underwent surgery at our institution were enrolled in this study. Fractures were classified according to the Müller AO classification system. Overall outcomes took the following into account: radiographic quality of reduction, evaluated using Ovadia and Beals' criteria; clinical assessment, evaluated using the AOFAS questionnaire; and general health, evaluated with the SF36-v2 Health Survey. Results. A total of 94 articular pilon fractures (34 type 43-B and 60 43-C) were evaluated with a mean follow-up of 56.34 months (range 33-101). The techniques used were ORIF, MIPO, and EF in 63 (67\%), 17 (18.9\%), and 14 cases (14.1\%), respectively. According to Ovadia and Beals' criteria, good, fair, and poor results were reported in 61 (64.89\%), 26 (27.66\%), and 7 (7.45\%) cases, respectively. The mean AOFAS score was 82.41 for MIPO, 79.83 for ORIF, and 50.57 for EF, respectively. Thirty-nine patients (41.49\%) presented early and/or late complications. Conclusion. Satisfactory outcomes using the three different techniques were reported. In particular, the radiographic outcomes were inversely proportional to the fracture comminutions and statistically different between internal and external osteosynthesis, but comparable between ORIF and MIPO techniques. On the other hand, the clinical outcomes were closely related to the soft tissue conditions and the anatomical reconstruction of the joint.
\end{abstract}

\section{Introduction}

Tibial pilon fractures are traumatic injuries of the distal part of the tibia involving its articular surface at the ankle joint $[1,2]$. They are generally uncommon, representing approximately $7-10 \%$ of all tibial fractures and $1-5 \%$ of lower limb fractures [3]. Pilon fractures are typically related to severe displacement of fragments, comminution, extensive soft tissue damage with bone exposure and lack of muscle cover, involvement of other skeletal segments, and visceral trauma $[3,4]$. Their outcomes are often unsatisfactory with a high percentage of complications [4]. Hence, tibial pilon fractures still represent a significant challenge for orthopaedic surgeons. Presently, nonoperative management using casts or pin traction is advocated by few orthopaedic surgeons and only for nondisplaced articular fractures or in patients who have surgical contraindications because of medical comorbidities, patients with low demand, and select inoperable cases $[4,5]$. The objective of operative treatment is to anatomically reduce the fracture fragments in order to restore the congruity of the joint surface and promote bony union and functional recovery with minimal disruption of soft tissues. To this end, several surgical techniques and staged procedure protocols have been proposed for treatment, including open reduction internal fixation (ORIF), minimally invasive plate osteosynthesis (MIPO), and external fixation 
$(\mathrm{EF})$, often followed by internal synthesis [6, 7]. However, none of these methods seems to be the ideal option for the management of soft tissue injuries and different fracture patterns, as pain, stiffness, and weakness persist for many months, sometimes becoming permanent. The traditional approach, involving an extensive soft tissue dissection to the distal tibia, originally described by Rüedi and Allgöwer [8], has been associated with significant rates of infection and wound dehiscence. Minimally invasive plating osteosynthesis (MIPO) is an alternative that enables indirect reduction and stable fixation with minimal soft tissue complication. However, it seems limited mainly to the treatment of extraarticular fractures (43A), only a few undisplaced articular fractures (43B1-C1), or cases of soft tissue lesions [9]. EF can be very useful as a temporary option for skeletal and soft tissue traction, but as a definitive treatment, it may result in malunion, pin-track infections, and ankle stiffness [10]. The purpose of this retrospective and observational study was to analyse, in a consecutive series of cases, the mediumlong-term clinical and radiographic results of the three most common surgical osteosynthesis techniques used for the treatment of articular tibial pilon fractures: ORIF, MIPO, and EF.

\section{Materials and Methods}

2.1. Setting and Patients. At our level-I healthcare trauma center, a 1,572-bed multidisciplinary and multispecialty regional university teaching hospital, from January 2006 to January 2013, a consecutive series of patients with diagnosis of tibial pilon fracture were treated surgically. All subjects participating in this retrospective and experimental study received a thorough explanation of the risks and benefits of inclusion and gave their oral and written informed consent to publish the data. The study was performed in accordance with the ethical standards of the 1964 Declaration of Helsinki as revised in 2000 .

2.2. Inclusion and Exclusion Criteria. All subjects considered in this study had to be older than 18 years, admitted to our Trauma Unit in the selected period, having undergone operative intervention for intra-articular fracture of the tibial pilon, isolated or with associated fibular fracture, having type 43-B or 43-C according to the Müller AO classification [11], and having provided informed consent to participate in the analysis. Specific patient exclusion criteria were as follows: paediatric patients, history of previous foot surgery or trauma, diagnosis of diabetes mellitus, cancer patients receiving chemotherapy and radiotherapy or with bone metastases, and patients with severe orthopaedic comorbidities (severe coxa-arthrosis, gonarthrosis, rheumatological diseases or psoriatic arthritis, diabetic foot neuropathy, vascular insufficiency).

2.3. Surgical Techniques, Postoperative Treatment, and Rehabilitation Program. All operative procedures were carried out by one of our trauma team surgeons, the 3 senior authors (I. C., S. S. P., and B. C.), with the help of two different residents of our institution. In all procedures, plexus anaesthesia was performed consisting in a regional block, which involved both sciatic and femoral nerves (biblock). Sedation was used when necessary. Antibiotic intravenous prophylaxis was administered with Cefazolin (1 g 4 times/day) and continued 24 hours after surgery in cases of closed fractures, while Ampicillin and Sulbactam (3 g 4 times/day) were administered and continued for a week in cases of bone exposure. Postoperative antithrombotic therapy (Natrium Enoxaparin) was given until weight bearing.

Without any calcaneal skeletal traction, three types of surgical techniques were performed, each with the patient supine on a radiolucent operating table: (1) traditional ORIF, limited to open reduction and internal fixation; (2) the more recent MIPO technique; and (3) EF, a two-stage management approach involving temporary external fixation followed by definitive open reduction and internal fixation, or a one-stage approach limited to definitive external fixation.

The following fixation methods were used:

(i) $3.5 \mathrm{~mm}$ Locking Compression Plate System (LCP) with additional lag screws (by DePuy Synthes) for ORIF and MIPO;

(ii) Prefix Fixator (by Orthofix, USA) for temporary stabilization EF (two-stage);

(iii) Procallus Fixator or the Hybrid Fixator (by Orthofix) for definitive EF (one-stage).

According to our institutional protocol, the choice to proceed directly with definitive fixation by ORIF or MIPO was based on the absence of any open injuries, good condition of soft tissue or recovery of soft tissue during the days after trauma, and the fracture pattern. Instead, the two-step procedure was chosen on the basis of critical patient condition, soft tissue injuries, important edema, fracture blisters, and fracture pattern. Finally, the decision to convert the EF from temporary to definitive was taken during outcome patient radiographic evaluation depending on the evolution of bone alignment and callus formation at the fracture site. The anteromedial surgical approach was used in all cases treated by the MIPO technique and in the majority of type 43-B fractures treated by ORIF, while the anterolateral approach was generally preferred for those 43-B fractures that were anterolateral partial articular and for type 43-C fractures. During ORIF and MIPO procedures, associated fibular fractures were first stabilized using a lateral approach with $3.5 \mathrm{~mm}$ LCP-DCP plates (by DePuy Synthes) or with temporary Kirschner wires. During these procedures, a thigh tourniquet was always applied only in cases of ORIF when any autogenous or allogeneic bone grafting was employed.

During the postoperative period, all patients were followed up and plain radiographs were obtained in the immediate postoperative time and at 1 and 3 months after surgery and every 6 months until fracture healing occurred, according to our standard aftercare algorithm. Partial weight bearing and exercises were started after callus formation, while full weight bearing was allowed after bone union. Finally, the external fixators were removed after bone union. 
2.4. Patient Assessment. Data collection was retrospectively performed during a period of 24 months, from September 2014 to August 2016, by an external and independent investigator (M. F.) not involved in the patients' treatment. Consulting the computerized archives of our hospital, we found that the following information was recorded: patients' age and gender, trauma mechanism, fracture type, closed or open (classified according to the Gustilo-Anderson criteria [12]), soft tissue condition after trauma, surgical technique performed, and time elapsed between trauma and surgery. The clinical and radiological analyses were carried out, respectively, by two independent researchers who were not directly involved in the patients' surgical treatment (C. D. and Z. M.).

2.5. Radiographic Outcome Measures. Radiographic data were obtained by reading the radiographic computerized images available in the computer system of our institute. The radiographic evaluation comprised the analysis of conventional radiographs including anterior-posterior ankle radiographic computerized images of all patients taken preoperatively, postoperatively, 1, 3, and 6 months after surgery, and at final follow-up. Further, a diagnostic LCD CORONIS $5 \mathrm{MP}$ display monitor (produced by Barco, Rome, Italy) was used to determine the fracture patterns and carry out the radiological analysis. The fractures were classified according to the Müller AO classification system [11], while the quality of operative reduction, the fractures' evolution, and healing were evaluated by analysing postoperative and last followup radiographs according to Ovadia and Beals' criteria [13]. These data are reported in Table 1.

2.6. Clinical Outcome Measures. At the time of this study, a phone contact was attempted for all patients who met inclusion criteria, and a follow-up appointment was fixed. Patients who returned were examined, and clinical results were measured with validated questionnaires. To quantify pain and functional disability, the American Orthopaedic Foot and Ankle Society (AOFAS) ankle-hindfoot scale questionnaire [14] was used. Overall physical and mental health were evaluated with the SF-36v2 (MOS short form questionnaire version 2) [15]. As the AOFAS ankle-hindfoot scale takes into account several subjective parameters, which vary according to patient age, our cohort was divided into two groups based on the median age of our sample, $\leq$ and $>52$ years. Finally, during the analysis, any early and late complications were recorded and then classified as being minor or major complications. Minor complications were defined as those successfully treated without affecting bone healing, while major complications as those requiring more extensive treatment and affecting bone healing.

2.7. Statistical Analysis. Statistical analysis was performed by an independent statistician (F. A. Ch.) from the Department of Statistics at our university, blinded to the type of technique treatment. Analysis of data was performed using SPSS statistical software. The relationship between treatment and AO fracture classification, type of fracture (open or closed), and conditions of skin and soft tissue complications after surgery were analyzed with the Chi-Square Test or Fisher Exact Test. The results of the SF-36v2 survey were used to compare treatment groups and the groups divided according to $\mathrm{AO}$ classification. The Wilcoxon Test was used for comparison between two groups, and the Kruskal-Wallis Rank Sum Test was used when more than two groups were involved. When the results of the Kruskal-Wallis Test were statistically significant, a post hoc Dunn Test of multiple comparisons was performed. Mean physical and mental components of SF36 were compared to mean data of the Italian population (confidence interval 95\%) [16] .

\section{Results}

3.1. Patient Data. One hundred and five patients with diagnosis of single tibial pilon fractures were treated surgically in our institution between January 2006 and September 2013. Among the 105 fractures investigated, 11 fractures were excluded from the study because the patients did not meet the inclusion criteria: one patient was undergoing chemotherapy for lung cancer, 4 patients had a history of diabetic foot, one was an amputee, 2 patients suffered severe ipsilateral coxarthrosis, and 3 patients presented severe ipsilateral gonarthrosis. Hence, a total of 94 enrolled patients (94 fractures) were included in this retrospective analysis, and all were available for clinical and radiographic follow-up at an average of 56.34 months (range 33-101). The patients' details are summarized in Table 2. They were 29 (30.85\%) females and $65(69.15 \%)$ males. The mean patient age at time of surgery was 52.44 years (range 19-90) with a median of 52 years. Trauma mechanisms were car accident $(36.16 \%)$, accidental fall (28.73\%), fall from height at workplace or at home $(24.47 \%)$, direct trauma like crushing (5.32\%), sports injury $(4.26 \%)$, and firearm trauma (1.06\%).

According to the Gustilo-Anderson classification [10], there were 7 (7.45\%) Grade I, 6 (6.38\%) Grade II, and 2 (13.2\%) Grade III open fractures. With regard to soft tissue conditions, $41(43.62 \%)$ patients showed soft tissue damage such as edema, severe swelling, blistering, skin abrasion, and open wounds. The 53 patients with intact skin were treated by a one-stage procedure protocol in $36(67.92 \%)$ cases, a twostage procedure protocol in $14(26.41 \%)$ cases, and definitive EF in $3(5.66 \%)$ cases. The 41 patients with soft tissue injuries were treated by a one-stage procedure protocol in $5(12.2 \%)$ cases, a two-stage in $25(60.97 \%)$ cases, and definitive EF in $11(26.83 \%)$ cases. The surgical techniques and treatment methods were performed as follows: ORIF in 63 cases $(67 \%)$, MIPO in 17 (18.9\%), and EF in 14 (14.1\%). The 79 closed fractures were treated by ORIF in 58 cases $(73.42 \%)$, MIPO in 16 cases $(20.25 \%)$, and definitive EF in 5 cases (6.33\%), while the 15 open fractures were treated by ORIF in 5 cases $(33.33 \%)$, MIPO in 1 case (6.67\%), and definitive EF in 9 cases (60\%).

3.2. Radiographic Outcomes. According to the Müller AO fracture classification [11], there were 34 (36.17\%) type 43-B and $60(63.83 \%)$ type $43-\mathrm{C}$ fractures. Closed fractures were reported in the majority of the cases, 79 (84.04\%), while 
TABLE 1: Ovadia and Beals score. The score sets a value of 0 for poor results, 2 for fair results, and 3 for good results. Adding the six variables, if the score goes from 0 to 6 , it is poor; if it goes from 7 to 12 , it is fair; if it goes from 13 to 18 , it is good.

\begin{tabular}{lccc}
\hline & \multicolumn{2}{c}{ Classification of fracture reduction } & \\
& Good & Fair & \\
Malleolus & & & \\
Lateral & Anatomical or & $2.0-5.0 \mathrm{~mm}$ & $>5.0 \mathrm{~mm}$ displacement \\
Medial & $\leq 1.0 \mathrm{~mm}$ displacement & displacement & $>5.0 \mathrm{~mm}$ displacement \\
Posterior & $\leq 2.0 \mathrm{~mm}$ displacement & $2.0-5.0 \mathrm{~mm}$ displacement & Proximal displacement \\
Mortise widening & Proximal displacement & Proximal displacement & $>5.0 \mathrm{~mm}$ \\
Talus & $\leq 2.0 \mathrm{~mm}$ & $2.0-5.0 \mathrm{~mm}$ & $>2.0 \mathrm{~mm}$ \\
Tilt & $\leq 0.5 \mathrm{~mm}$ & $0.5-2.0 \mathrm{~mm}$ & $>1.0 \mathrm{~mm}$ \\
Displacement & & & $>2.0 \mathrm{~mm}$ \\
\hline
\end{tabular}

open fractures only in $15(15.96 \%)$ cases. According to Ovadia and Beals' criteria [13] at the last follow-up, the radiographic results of our cohort were classified as good, fair, and poor in $61(64.89 \%), 26(27.66 \%)$, and $7(7.45 \%)$ cases. For each technique, they were good in 45 cases $(71.42 \%)$, fair in 16 (25.39\%), and poor in 2 cases $(3.17 \%)$ when treated by ORIF; good in $14(82.35 \%)$ and fair in 3 cases $(17.65 \%)$ when treated by MIPO; finally, good in 2 cases (14.28\%), fair in 7 (50\%), and poor in $5(35.71 \%)$ when treated by EF. The radiographic outcomes of our cohort are summarized in Table 3, while one case for each treatment technique is reported in Figures 1, 2, and 3 .

3.3. Clinical Outcomes. The mean overall AOFAS anklehindfoot score was 73.3 (18-100) with a standard deviation of \pm 20.8 . The results of the AOFAS ankle-hindfoot score calculated in the 2 groups according to the median age of the sample ( $\leq$ and $>52$ years) were $81.8( \pm 15.51)$ and $70.6( \pm 24.24)$, respectively. Patients treated by ORIF, MIPO, and EF as a definitive treatment achieved a mean score of 79.83, 82.41, and 50.77 , respectively. The mean $( \pm \mathrm{SD})$ AOFAS score of patients who did not develop complications was higher than those of patients who developed complications, $81.2( \pm 18.66)$ versus 68.31 ( \pm 22.86$)$. Regarding the SF-36v2 survey, the mean PCS score of our cohort was 44.3 (range $62-17.7$ ): 45.72 for ORIF, 49.02 for MIPO, and 33.18 for EF. The mean MCS score of the sample was 45.76 (range 60.2-17.7): 46.13 for ORIF, 49.39 for MIPO, and 39.73 for EF. The clinical outcomes are also summarized in Table 3.

Complications were reported in 39 patients (41.49\%). There were 20 early complications $(21.28 \%)$, all minor: 12 (12.77\%) superficial infections including pin-track infection and $5(5.32 \%)$ wound dehiscence, which were effectively resolved with local therapy and oral antibiotics; 3 (3.19\%) cases of deep venous thrombosis which were treated successfully first by LMWH and then by warfarin therapy. Late complications occurred in 19 patients (20.21\%), including 17 major ones (18.08\%): 7 (7.44\%) delayed union, 4 (4.26\%) osteomyelitis, $3(3.19 \%)$ malunions, $3(3.19 \%)$ loss of reduction, and $2(2.13 \%)$ minor complications, such as Sudeck syndrome. No cases of compartment syndrome or secondary bone necrosis were noted, neither rupture of metalwork nor anchorage elements of the EF, while the 3 patients having loss of reduction necessitated revision of their Procallus Fixators. Hence, in our series, 22 cases (23.40\%) experienced minor complication, while 17 (18.09\%) experienced major complications (Table 4).

\section{Discussion}

The purpose of the present retrospective, nonrandomized, case series study was to evaluate the medium-long-term clinical and radiographic results of the three most commonly performed surgical techniques used to treat tibial pilon fractures $[1,4]$ : ORIF, MIPO, and EF. In line with other comparable studies $[1,15]$, the most common technique used in our cohort was ORIF, which was performed more frequently in both type B (73.53\%) and C fractures (58.33\%) $(p<0.05)$. As the use of the definitive external fixation procedure or the two-stage procedure protocol, in combination with ORIF, represents the gold standard of treatment of pilon fractures in cases of associated soft tissue lesions [17-27], the choice between the one- and two-stage procedure standard protocol in our case series was made in the majority of cases on the basis of the state of the soft tissues $(p<0.05)$ according to our institutional protocol and in a few cases on the basis of the preferences and experience of the surgeons involved in the operations. Further, the choice of using the Procallus Fixator or the Hybrid Fixator for definitive treatment (one-stage procedure) instead of the circular frame was mainly made for biomechanical reasons. In contrast with other authors $[28,29]$, we believe that the traditional ring fixator is not indicated for the treatment of these fractures, as it has only a mechanical stabilization function without the dynamization exerted by the elasticity of the K-wires during early weight bearing, which is not permitted in these injuries. Further, the Hybrid Fixator is preferred to avoid the rings' application on the proximal leg, which is poorly tolerated by patients.

Despite the severity of the injuries in our sample and their poor prognoses [19], satisfactory radiographic and clinical outcomes were achieved. Regarding radiographic aspects, Ovadia and Beals scores were compared with the AO 
TABLE 2: Patient and fracture characteristics of our cohort.

\begin{tabular}{|c|c|c|c|c|c|c|c|c|c|c|c|}
\hline $\mathrm{N}^{\circ}$ & Gender & Age & $\begin{array}{c}\text { FW-UP } \\
\text { (months) }\end{array}$ & $\mathrm{AO}$ & Technique & Ovadia & AOFAS & $\begin{array}{l}\text { SF36 } \\
\text { (PSC) }\end{array}$ & $\begin{array}{c}\text { SF36 } \\
\text { (MCS) }\end{array}$ & Gustilo & TISS.DAMAGE \\
\hline (1) & M & 49 & 69 & $\mathrm{C} 2$ & ORIF & Fair & 47 & 22.8 & 35.6 & & Yes \\
\hline (2) & M & 70 & 54 & B3 & ORIF & Fair & 78 & 45.2 & 44.3 & & \\
\hline (3) & $\mathrm{F}$ & 46 & 47 & $\mathrm{~B} 1$ & MIPO & Good & 95 & 55.3 & 46.8 & I & Yes \\
\hline (4) & $\mathrm{F}$ & 49 & 39 & $\mathrm{C} 2$ & MIPO & Good & 100 & 55.5 & 57.2 & & \\
\hline (5) & $\mathrm{F}$ & 20 & 65 & $\mathrm{~B} 1$ & ORIF & Good & 78 & 47.1 & 44.1 & & \\
\hline (6) & M & 28 & 49 & $\mathrm{C} 1$ & ORIF & Good & 90 & 55.37 & 50.8 & & \\
\hline (7) & $\mathrm{F}$ & 22 & 34 & $\mathrm{C} 2$ & ORIF & Good & 94 & 38.5 & 42.3 & & Yes \\
\hline (8) & M & 51 & 45 & $\mathrm{C} 3$ & $\mathrm{EF}$ & Fair & 53 & 20.5 & 55.1 & & \\
\hline (9) & M & 20 & 67 & $\mathrm{C} 2$ & ORIF & Good & 89 & 45.6 & 30.1 & & Yes \\
\hline (10) & M & 61 & 46 & $\mathrm{C} 3$ & ORIF & Good & 96 & 55.5 & 60.2 & & Yes \\
\hline (11) & $\mathrm{F}$ & 20 & 42 & $\mathrm{C} 1$ & ORIF & Good & 100 & 54.4 & 60.0 & & \\
\hline (12) & M & 79 & 72 & $\mathrm{C} 1$ & ORIF & Fair & 41 & 21.6 & 31.2 & & Yes \\
\hline (13) & $\mathrm{F}$ & 70 & 60 & $\mathrm{C} 1$ & ORIF & Good & 77 & 44.3 & 46.3 & & \\
\hline (14) & M & 41 & 58 & $\mathrm{C} 3$ & ORIF & Fair & 58 & 32.9 & 50.8 & I & Yes \\
\hline (15) & M & 20 & 46 & $\mathrm{~B} 1$ & ORIF & Good & 96 & 51.3 & 45.8 & & \\
\hline (16) & M & 59 & 54 & B3 & ORIF & Good & 93 & 57.0 & 54.3 & & \\
\hline (17) & M & 49 & 39 & B3 & ORIF & Good & 95 & 50.8 & 55.37 & & \\
\hline (18) & M & 69 & 43 & $\mathrm{~B} 2$ & ORIF & Good & 98 & 51.0 & 44.5 & & \\
\hline (19) & M & 43 & 50 & $\mathrm{C} 2$ & MIPO & Good & 97 & 50.1 & 53.6 & & \\
\hline (20) & M & 60 & 47 & $\mathrm{C} 2$ & ORIF & Good & 98 & 55.5 & 60.0 & & \\
\hline (21) & $\mathrm{F}$ & 64 & 79 & $\mathrm{C} 3$ & ORIF & Fair & 89 & 46.8 & 57.1 & & Yes \\
\hline (22) & M & 27 & 48 & $\mathrm{C} 1$ & ORIF & Good & 100 & 55.6 & 60.9 & & \\
\hline (23) & $\mathrm{F}$ & 65 & 42 & $\mathrm{C} 1$ & ORIF & Good & 88 & 46.2 & 55.9 & & \\
\hline (24) & M & 64 & 66 & $\mathrm{C} 3$ & $\mathrm{EF}$ & Poor & 20 & 20.6 & 17.7 & III & Yes \\
\hline (25) & M & 37 & 38 & $\mathrm{C} 2$ & MIPO & Good & 71 & 35.2 & 37.1 & & \\
\hline (26) & $\mathrm{F}$ & 52 & 74 & $\mathrm{C} 2$ & ORIF & Fair & 61 & 43.9 & 44.1 & & Yes \\
\hline (27) & $\mathrm{F}$ & 33 & 37 & $\mathrm{C} 2$ & ORIF & Good & 100 & 57.0 & 55.5 & & \\
\hline (28) & M & 85 & 100 & B2 & MIPO & Fair & 52 & 33.3 & 35.5 & & \\
\hline (29) & $\mathrm{F}$ & 19 & 44 & B2 & MIPO & Good & 90 & 44.7 & 46.8 & & \\
\hline (30) & $\mathrm{F}$ & 22 & 67 & $\mathrm{C} 2$ & ORIF & Poor & 44 & 21.7 & 22.5 & & Yes \\
\hline (31) & M & 82 & 63 & $\mathrm{C} 3$ & MIPO & Good & 78 & 56.0 & 53.4 & & Yes \\
\hline$(32)$ & $\mathrm{F}$ & 52 & 56 & $\mathrm{C} 3$ & ORIF & Fair & 50 & 25.7 & 47.2 & I & Yes \\
\hline (33) & M & 29 & 39 & B2 & ORIF & Good & 90 & 49.8 & 33.2 & & Yes \\
\hline (34) & M & 43 & 57 & $\mathrm{C} 1$ & $\mathrm{EF}$ & Poor & 60 & 38.0 & 28.0 & II & Yes \\
\hline (35) & M & 83 & 97 & $\mathrm{C} 3$ & $\mathrm{EF}$ & Poor & 29 & 17.7 & 27.6 & III & Yes \\
\hline (36) & M & 56 & 44 & $\mathrm{C} 1$ & ORIF & Good & 98 & 59.9 & 58.0 & & \\
\hline (37) & M & 78 & 76 & B3 & ORIF & Poor & 39 & 30.2 & 19.2 & I & Yes \\
\hline (38) & $\mathrm{F}$ & 88 & 34 & $\mathrm{C} 3$ & ORIF & Fair & 45 & 24.5 & 46.1 & & \\
\hline (39) & M & 64 & 46 & $\mathrm{C} 2$ & MIPO & Good & 88 & 48.9 & 51.6 & & \\
\hline (40) & M & 23 & 76 & $\mathrm{C} 3$ & ORIF & Good & 96 & 57.8 & 58.9 & & Yes \\
\hline (41) & M & 63 & 35 & $\mathrm{C} 1$ & ORIF & Good & 82 & 43.0 & 51.8 & & \\
\hline$(42)$ & $\mathrm{F}$ & 41 & 39 & $\mathrm{~B} 1$ & MIPO & Good & 100 & 62 & 60.9 & & \\
\hline (43) & M & 45 & 39 & $\mathrm{C} 2$ & ORIF & Good & 86 & 48.1 & 42.5 & & Yes \\
\hline (44) & $\mathrm{F}$ & 74 & 37 & $\mathrm{C} 1$ & MIPO & Good & 90 & 58.2 & 53.0 & & \\
\hline (45) & M & 42 & 70 & B2 & EF & Fair & 68 & 46.7 & 36.1 & & Yes \\
\hline (46) & M & 34 & 61 & B2 & ORIF & Good & 96 & 53.2 & 56.2 & & \\
\hline (47) & M & 68 & 37 & B3 & ORIF & Fair & 65 & 37.9 & 35.4 & & \\
\hline$(48)$ & $\mathrm{M}$ & 81 & 45 & $\mathrm{C} 2$ & ORIF & Fair & 59 & 23.8 & 32.2 & & Yes \\
\hline
\end{tabular}


TABLE 2: Continued.

\begin{tabular}{|c|c|c|c|c|c|c|c|c|c|c|c|}
\hline $\mathrm{N}^{\circ}$ & Gender & Age & $\begin{array}{c}\text { FW-UP } \\
\text { (months) }\end{array}$ & $\mathrm{AO}$ & Technique & Ovadia & AOFAS & $\begin{array}{c}\text { SF36 } \\
\text { (PSC) }\end{array}$ & $\begin{array}{c}\text { SF36 } \\
\text { (MCS) }\end{array}$ & Gustilo & TISS.DAMAGE \\
\hline (49) & $\mathrm{F}$ & 60 & 69 & B3 & ORIF & Good & 78 & 42.8 & 42.3 & & Yes \\
\hline$(50)$ & $\mathrm{F}$ & 36 & 88 & B2 & MIPO & Good & 58 & 42.1 & 44.8 & & \\
\hline$(51)$ & $\mathrm{F}$ & 52 & 41 & $\mathrm{C} 2$ & ORIF & Good & 96 & 57.9 & 44.5 & & \\
\hline (52) & $\mathrm{M}$ & 87 & 67 & B3 & ORIF & Fair & 78 & 43.6 & 49.2 & & \\
\hline (53) & $\mathrm{M}$ & 24 & 33 & B3 & ORIF & Fair & 48 & 35.9 & 21.1 & I & Yes \\
\hline (54) & $\mathrm{M}$ & 67 & 67 & $\mathrm{C} 1$ & ORIF & Good & 68 & 23.3 & 42.5 & & Yes \\
\hline (55) & $\mathrm{M}$ & 19 & 37 & B3 & ORIF & Good & 82 & 55.9 & 35.1 & & \\
\hline$(56)$ & M & 72 & 35 & B3 & ORIF & Good & 89 & 56.9 & 56.33 & & \\
\hline$(57)$ & M & 39 & 85 & $\mathrm{C} 3$ & ORIF & Fair & 70 & 47.8 & 58.2 & & Yes \\
\hline$(58)$ & $\mathrm{M}$ & 23 & 42 & $\mathrm{C} 2$ & MIPO & Good & 90 & 57.3 & 58.9 & & \\
\hline (59) & $\mathrm{M}$ & 88 & 70 & $\mathrm{C} 2$ & $\mathrm{EF}$ & Poor & 38 & 19.5 & 25.7 & II & Yes \\
\hline$(60)$ & $\mathrm{M}$ & 84 & 83 & $\mathrm{C} 2$ & $\mathrm{EF}$ & Fair & 70 & 44.5 & 49.5 & I & Yes \\
\hline$(61)$ & $\mathrm{F}$ & 60 & 67 & $\mathrm{C} 1$ & ORIF & Good & 88 & 44.9 & 51.7 & & \\
\hline$(62)$ & $\mathrm{F}$ & 46 & 40 & B3 & ORIF & Fair & 65 & 45.8 & 43.0 & & Yes \\
\hline$(63)$ & M & 83 & 71 & $\mathrm{C} 3$ & $\mathrm{EF}$ & Fair & 47 & 36.4 & 45.2 & & Yes \\
\hline (64) & M & 21 & 51 & B3 & ORIF & Good & 100 & 57.0 & 60.1 & & \\
\hline$(65)$ & M & 47 & 61 & $\mathrm{C} 3$ & MIPO & Good & 94 & 56.2 & 59.1 & & Yes \\
\hline$(66)$ & M & 61 & 68 & $\mathrm{C} 2$ & ORIF & Good & 83 & 43.6 & 44.5 & & \\
\hline$(67)$ & M & 82 & 52 & $\mathrm{C} 1$ & ORIF & Good & 62 & 43.9 & 46.9 & & Yes \\
\hline$(68)$ & M & 52 & 93 & B3 & MIPO & Fair & 60 & 39.8 & 41.2 & & \\
\hline (69) & $\mathrm{F}$ & 29 & 36 & $\mathrm{C} 2$ & $\mathrm{EF}$ & Good & 90 & 57.4 & 57.2 & & \\
\hline$(70)$ & $\mathrm{M}$ & 32 & 59 & $\mathrm{C} 2$ & ORIF & Good & 92 & 44.9 & 42.1 & & \\
\hline$(71)$ & $\mathrm{M}$ & 72 & 38 & $\mathrm{C} 1$ & MIPO & Fair & 75 & 40.5 & 39.4 & & \\
\hline$(72)$ & $\mathrm{F}$ & 35 & 48 & $\mathrm{C} 2$ & MIPO & Good & 76 & 42.1 & 44.6 & & \\
\hline (73) & $\mathrm{M}$ & 76 & 35 & $\mathrm{C} 1$ & ORIF & Good & 98 & 37.0 & 44.0 & & \\
\hline$(74)$ & M & 75 & 40 & B1 & MIPO & Good & 87 & 56.2 & 55.8 & & \\
\hline$(75)$ & $\mathrm{F}$ & 38 & 60 & B2 & ORIF & Good & 100 & 57.6 & 51.9 & & \\
\hline$(76)$ & $\mathrm{F}$ & 90 & 101 & B3 & ORIF & Fair & 54 & 38.5 & 23.2 & & Yes \\
\hline (77) & $\mathrm{M}$ & 30 & 45 & B3 & ORIF & Good & 90 & 60.1 & 56.5 & & \\
\hline (78) & M & 40 & 49 & $\mathrm{C} 2$ & ORIF & Good & 98 & 57.6 & 39.8 & & \\
\hline (79) & $\mathrm{M}$ & 75 & 62 & $\mathrm{C} 2$ & ORIF & Good & 87 & 46.9 & 55.9 & & \\
\hline$(80)$ & $\mathrm{F}$ & 83 & 49 & C3 & $\mathrm{EF}$ & Fair & 32 & 30.1 & 39.9 & II & Yes \\
\hline$(81)$ & $\mathrm{M}$ & 77 & 97 & $\mathrm{C} 2$ & $\mathrm{EF}$ & Poor & 43 & 22.4 & 30.0 & II & Yes \\
\hline$(82)$ & $\mathrm{F}$ & 77 & 82 & $\mathrm{C} 1$ & ORIF & Good & 53 & 22.6 & 39.8 & & Yes \\
\hline (83) & $\mathrm{F}$ & 21 & 73 & $\mathrm{C} 2$ & ORIF & Good & 100 & 60.1 & 49.5 & & \\
\hline (84) & $\mathrm{M}$ & 31 & 74 & B3 & ORIF & Good & 85 & 46.2 & 53.2 & & \\
\hline (85) & $\mathrm{F}$ & 79 & 68 & $\mathrm{C} 1$ & ORIF & Good & 68 & 47.1 & 44.6 & & Yes \\
\hline (86) & $\mathrm{M}$ & 48 & 66 & B3 & $\mathrm{EF}$ & Fair & 42 & 21.3 & 42.5 & II & Yes \\
\hline (87) & $\mathrm{M}$ & 64 & 36 & $\mathrm{C} 2$ & $\mathrm{EF}$ & Good & 78 & 56.1 & 56.9 & & Yes \\
\hline (88) & $\mathrm{M}$ & 23 & 41 & B3 & ORIF & Good & 81 & 52.0 & 41.3 & & \\
\hline (89) & $\mathrm{M}$ & 58 & 61 & B3 & $\mathrm{EF}$ & Fair & 38 & 19.3 & 44.8 & II & Yes \\
\hline$(90)$ & $\mathrm{M}$ & 60 & 65 & $\mathrm{C} 3$ & ORIF & Good & 94 & 56.4 & 57.8 & & Yes \\
\hline (91) & $\mathrm{M}$ & 34 & 59 & B2 & ORIF & Good & 100 & 54.1 & 43.4 & & \\
\hline$(92)$ & $\mathrm{M}$ & 45 & 54 & B2 & ORIF & Fair & 80 & 37.3 & 32.1 & I & Yes \\
\hline (93) & $\mathrm{M}$ & 30 & 63 & $\mathrm{C} 1$ & ORIF & Good & 91 & 52.3 & 46.2 & & \\
\hline (94) & $\mathrm{M}$ & 65 & 43 & $\mathrm{C} 1$ & ORIF & Good & 96 & 56.33 & 56.9 & & \\
\hline
\end{tabular}

Distribution of the type of fracture according to Ovadia and Beals criteria in the analyzed patient series. FW-UP: follow-up, TISS.DAMAGE: tissue damage. 
TAble 3: * In these cases the definitive EF was used due to the severity of tissue damage and bad local skin conditions at the time of trauma.

\begin{tabular}{|c|c|c|c|c|c|c|c|c|c|c|c|c|}
\hline \multirow[t]{2}{*}{ AO classification } & \multicolumn{2}{|c|}{$\begin{array}{c}\text { Surgical } \\
\text { techniques }\end{array}$} & \multicolumn{3}{|c|}{ Ovadia \& Beals criteria } & \multirow[t]{2}{*}{ AOFAS } & \multirow[t]{2}{*}{ PCS } & \multirow[t]{2}{*}{ MCS } & \multicolumn{3}{|c|}{$\begin{array}{l}\text { Gustilo \& Anderson } \\
\text { open fracture }\end{array}$} & \multirow[t]{2}{*}{$\begin{array}{l}\text { Tissue } \\
\text { damage }\end{array}$} \\
\hline & Type & $\mathrm{N}^{\circ}$ & Good & Fair & Poor & & & & I & II & III & \\
\hline \multirow{3}{*}{ 43-B1 } & MIPO & 3 & 3 & - & - & 94.0 & 57.8 & 54.5 & 1 & - & - & 1 \\
\hline & ORIF & 2 & 2 & - & - & 87.0 & 49.2 & 45.0 & - & - & - & - \\
\hline & EF & - & - & - & - & - & - & - & - & - & - & - \\
\hline \multirow{3}{*}{$43-\mathrm{B} 2$} & MIPO & 3 & 2 & 1 & - & 66.7 & 40.0 & 42.4 & - & - & - & - \\
\hline & ORIF & 6 & 5 & 1 & - & 94.0 & 52.5 & 43.6 & 1 & - & - & 2 \\
\hline & $\mathrm{EF}$ & $1^{*}$ & - & 1 & - & 68.0 & 46.7 & 36.1 & - & - & - & 1 \\
\hline \multirow{3}{*}{$43-\mathrm{B} 3$} & MIPO & 1 & - & 1 & - & 60.0 & 39.8 & 41.2 & - & - & - & - \\
\hline & ORIF & 16 & 9 & 6 & 1 & 76.3 & 47.2 & 43.1 & 2 & - & - & 5 \\
\hline & $\mathrm{EF}$ & $2^{*}$ & - & 2 & - & 40.0 & 20.3 & 43.7 & - & 2 & - & 2 \\
\hline \multirow{3}{*}{$43-\mathrm{Cl}$} & MIPO & 2 & 1 & 1 & - & 82.5 & 49.4 & 46.2 & - & - & - & - \\
\hline & ORIF & 16 & 15 & 1 & - & 81.3 & 44.2 & 49.2 & - & - & - & 5 \\
\hline & $\mathrm{EF}$ & 1 & - & - & 1 & 60.0 & 38.0 & 28.0 & - & 1 & - & 1 \\
\hline \multirow{3}{*}{$43-\mathrm{C} 2$} & MIPO & 6 & 6 & - & - & 87.0 & 48.2 & 50.5 & - & - & - & - \\
\hline & ORIF & 15 & 11 & 3 & 1 & 82.3 & 44.5 & 42.7 & - & - & - & 7 \\
\hline & EF & 5 & 2 & 1 & 2 & 63.8 & 40.0 & 43.9 & 1 & 2 & - & 4 \\
\hline \multirow{3}{*}{$43-\mathrm{C} 3$} & MIPO & 2 & 2 & - & - & 86.0 & 56.1 & 56.3 & - & - & - & 2 \\
\hline & ORIF & 8 & 3 & 5 & - & 74.8 & 43.4 & 54.2 & 2 & - & - & 7 \\
\hline & $\mathrm{EF}$ & 5 & - & 3 & 2 & 36.2 & 25.1 & 37.1 & - & 1 & 2 & 4 \\
\hline
\end{tabular}

TABLE 4: Complications recorded in our patient cohort after treatment. $\mathrm{N}^{\circ}$ : number of patients; \%: percentage of patients referred to the whole cohort.

\begin{tabular}{lc}
\hline Complications & $\mathrm{N}^{\circ} ;(\%)$ \\
\hline Whole cohort & $39 ;(41.49)$ \\
\hline Early complications: & $20 ;(21.28)$ \\
(i) Superficial infection & $12 ;(12.77)$ \\
(ii) Wound dehiscence & $5 ;(5.32)$ \\
(iii) DVT & $3 ;(3.19)$ \\
\hline Late complications: & $19 ;(20.21)$ \\
(i) Delayed union & $7 ;(7.44)$ \\
(ii) Osteomyelitis & $4 ;(4.26)$ \\
(iii) Malunions & $3 ;(3.19)$ \\
(iv) Loss of reduction & $3 ;(3.19)$ \\
(v) Sudeck syndrome & $2 ;(3.19)$ \\
\hline
\end{tabular}

classification of fractures, revealing a statistically significant difference $(p<0.05)$, as reported by other authors [24, 25]. In accordance with the recent literature [24, 25, 30, 31], joint reconstruction was achieved significantly better by ORIF and MIPO techniques compared to EF $(p<0.05)$, while no statistically significant differences were reported between ORIF and MIPO ( $p>0.05)$. In our series, the quality of joint reconstruction depended on the type of fracture. In agreement with the data reported by Korkmaz et al. [31], the reconstruction quality of open fractures was worse. Specifically, good Ovadia and Beals scores were obtained in closed (68.57\%) and open (40\%) fractures, while poor results were recorded only in a few cases $(5.71 \%)$ of closed fractures versus $30 \%$ for exposed ones $(p<0.05)$.

Regarding clinical outcomes, the average AOFAS score of our cohort was 76.59 points (range 20-100), with $54.25 \%$ of our patients scoring between 80 and 100 points, while only $1.06 \%$ of our patients achieved very low results (0-20 points). Further, when AOFAS average scores were evaluated in comparison to the AO classification fracture types and their subgroups, no statistically significant difference among them was noted $(p>0.05)$. However, when AOFAS average scores were evaluated in comparison to the 3 different surgical techniques, the scores reported for ORIF (79.83), MIPO (82.41 points), and EF (50.57) were found to be of borderline significance $(p=0.0518)$. Although comparable results are reported in similar studies [31-33], we believe the lack of statistical significance in relation to the surgical technique used in our cohort may be attributable to several subjective parameters that the AOFAS questionnaire takes into account. This score seems to reflect the age of the patients and associated possible comorbidities rather than the true posttrauma foot and ankle clinical situation; the AOFAS average scores were statistically significant only in patients younger than 52 years $(p<0.05)$. As found in other studies $[9,10]$, AOFAS scores in our cohort were predictably lower in patients who developed postoperative complications compared to patients who did not $(p<0.05)$. Specifically, the correlation assessed between AOFAS and Ovadia and Beals scores was statistically significant $(p<0.01)$. In agreement with Korkmaz et al. [31], our data show that also the functional AOFAS index was closely related to the quality of joint reconstruction. 


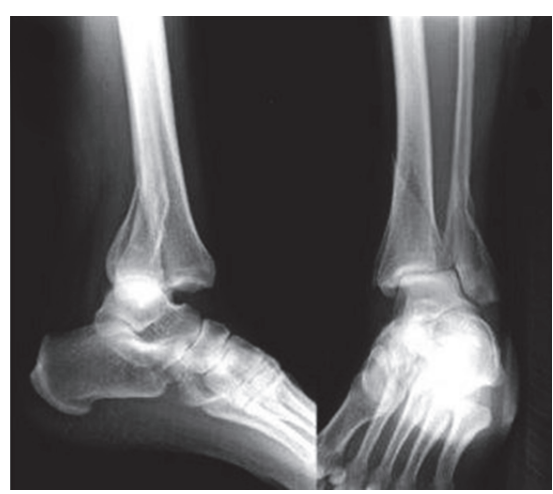

(a)

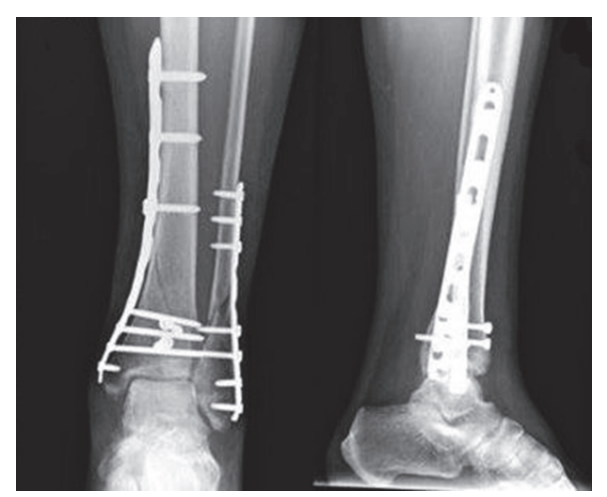

(b)

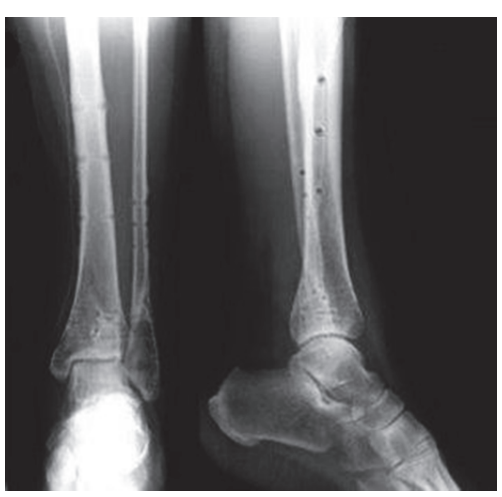

(c)

FIGURE 1: Case $N^{\circ}$ (42) of Table 2: a 41-year-old woman with a 43-B1 closed fracture treated with MIPO technique: (a) preoperative radiographic image; (b) postoperative radiographic image at 1-month follow-up; (c) radiographic aspect at 39-month follow-up after implant removal.

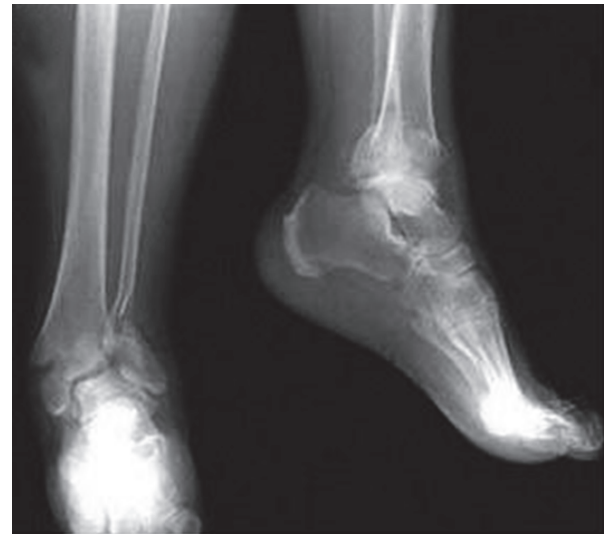

(a)

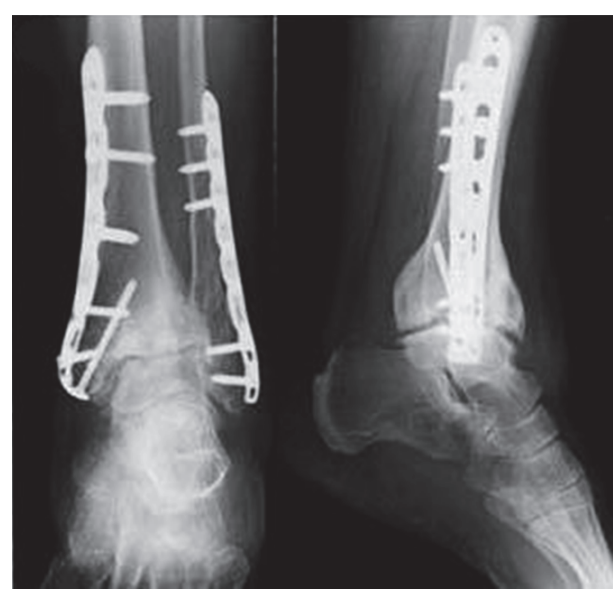

(c)

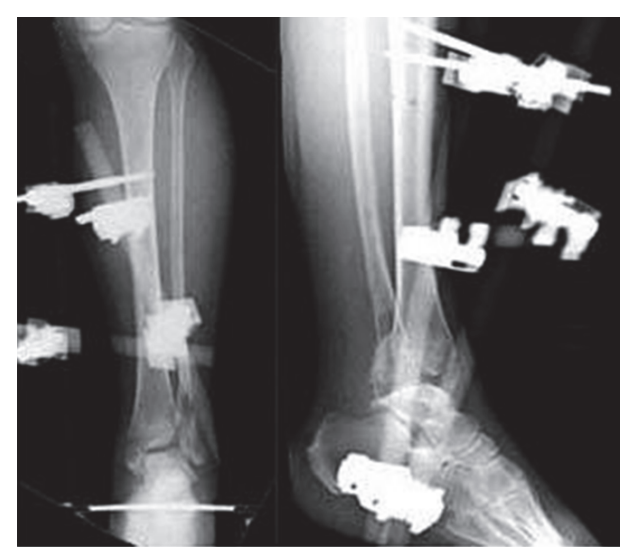

(b)

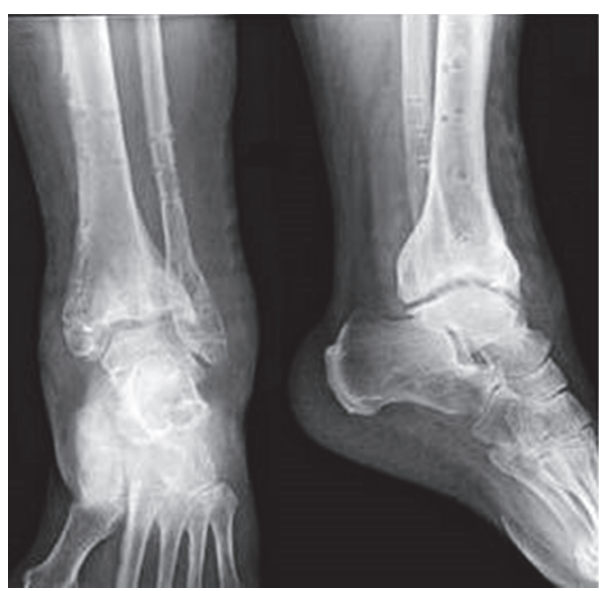

(d)

Figure 2: Case $N^{\circ}$ (47) of Table 2: a 68-year-old man with a 43-B3 closed fracture treated with two-stage ORIF technique: (a) preoperative radiographic image; (b) after prefix implant, radiographic image; (c) definitive implant after 16 days, 1-month follow-up; (d) radiographic aspect at 37-month follow-up after implant removal.

Dividing the cohort based on the type of treatment, the results obtained by the SF-36v2 questionnaire were higher on average in the group of patients operated by MIPO (49.02 points), slightly lower in that operated by ORIF (45.72), and lower (33.18) in the group treated by EF for the physical component of the score (PCS). The results were similar for the mental component summary (MCS). No significant differences between mean PCS and MCS scores were reported 

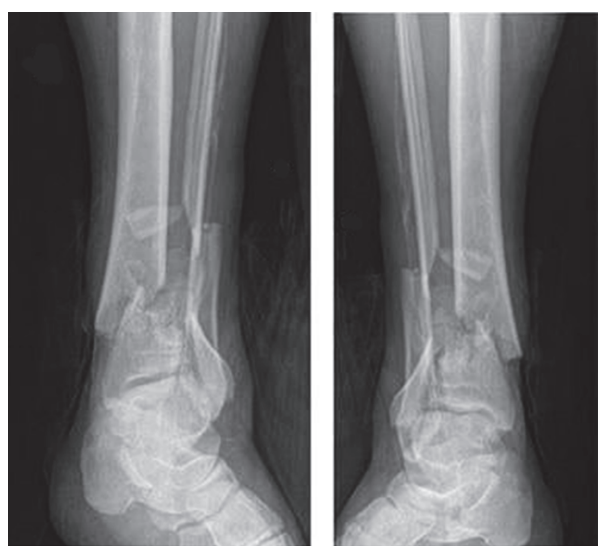

(a)

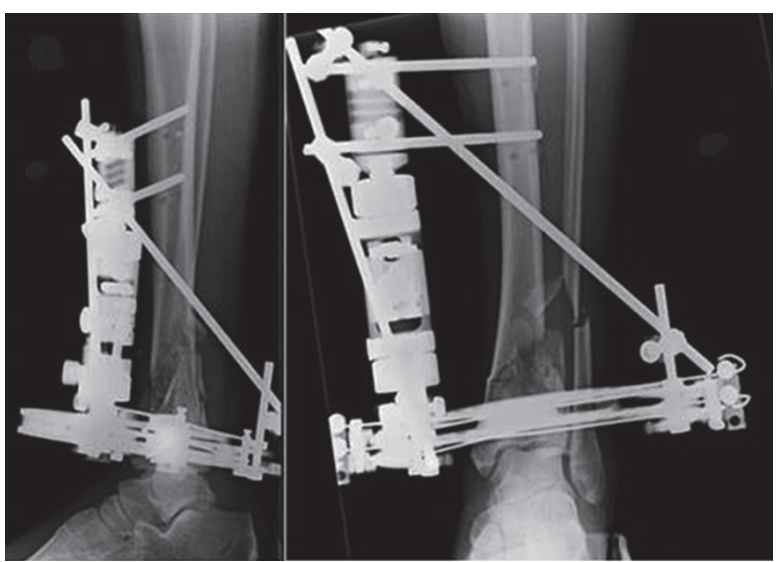

(c)

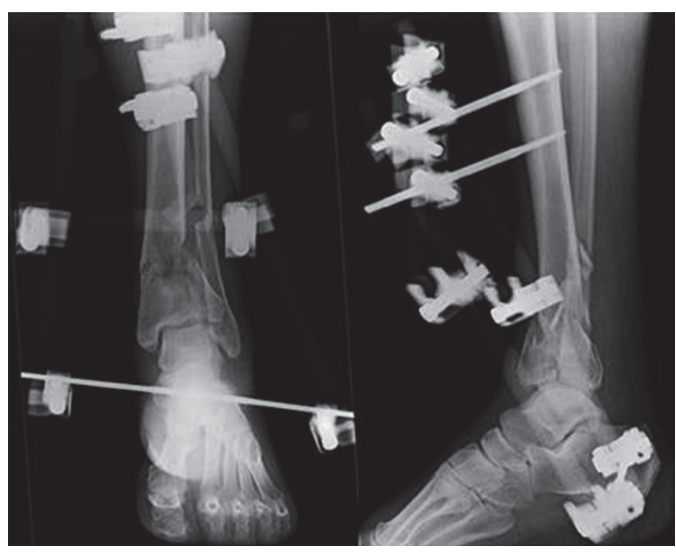

(b)

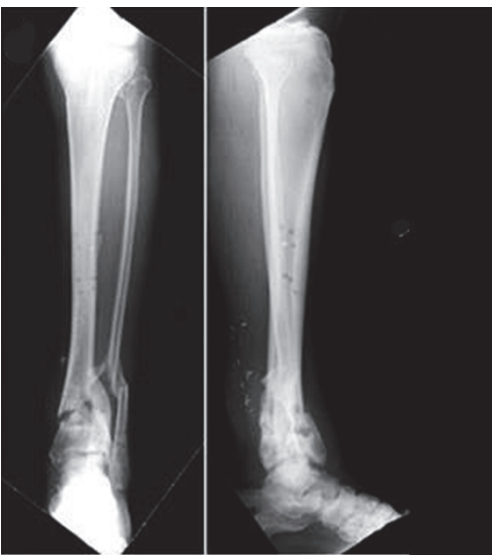

(d)

FIGURE 3: Case $N^{\circ}$ (34) of Table 2: a 43-year-old man with a 43-C1 open fracture (Gustilo II) treated with hybrid external fixator: (a) preoperative radiographic image; (b) after prefix implant, radiographic image; (c) definitive EF implant after 1 week, radiographic image; (d) radiographic aspect at 57-month follow-up after implant removal.

between the three techniques $(p>0.05)$, neither were significant differences found between PCS, MCS, and the AO classification fracture types and subtypes $(p>0.05)$. Similar results are reported in the literature [21,34-36], obtaining a statistically significant difference only by dividing the sample into age groups and comparing the results with the general population [17]. Finally, the average score for the physical component of the SF-36v2 of the patients in our sample (44.17 points) was compared with the average score of the same index of the Italian population (50 points) [16]. In the literature, some studies have found similar results, getting even lower scores when taking into account only the most serious fractures [18, 20-23].

Because of the high incidence of complications with poor outcomes reported in pilon fracture management [19, $26,27,30,31]$, several authors $[19,27,30]$ have tried to make their surgical approaches less invasive to limit damage of soft tissues. In our cohort, 39 patients (41.49\%) showed early and/or late complications, rates comparable to those described in the literature [27, 31]. However, 22 cases (23.40\%) experienced early minor complications, including superficial infections, pin-track infections, or wound dehiscence, which were effectively treated by periodic medication, sometimes in association with oral antibiotic therapy for a few days. It is well known that pin-track infection is a frequent complication of this surgical treatment that rarely leads to osteomyelitis, neither does it affect the final outcome [19]. On the contrary, 17 cases (18.08\%) experienced major complications, which required further treatment, including nonunion, deep infections, and osteomyelitis. Comparing these findings with the three surgical techniques adopted, they were statistically significant $(p<0.05)$. Specifically, MIPO was correlated to lower complication rates, as this technique is less invasive and preserves soft tissue, which is often seriously damaged before surgery $[1,37,38]$. However, minimally invasive techniques may not permit adequate visualization of the joint surface and achieve an anatomic reduction, with the frequent result of inadequate joint surface reconstruction [19]. Hence, we believe MIPO is not indicated for severely comminuted articular fractures for which ORIF is recommended except in cases of soft tissue lesions when temporary or definitive external fixation should be used. 
Selection and assessor biases are always possible, primarily in cases of nonconformity of a standardized protocol. Our patients were treated individually, according to our institutional protocol, sometimes influenced by one of three surgeons' preferences. Several potential limitations and some biases may have influenced this case series study, mainly linked to its retrospective design and the consequent lack of randomization and an identified control group. At the time of the operation no preoperative CT scan planning was performed, neither did our study protocol provide CT scans in the postoperative period for radiographic evaluation. As this report is retrospective, it was difficult in the aftermath to precisely classify the soft tissue conditions at the time of trauma only on the basis of patients' clinical notes. Hence, we recorded only the presence or absence of soft tissue damage rather than using a recognized international classification, which would have been difficult to apply retrospectively. Further, no bone grafting was used for the treatment of the cases included in this study, although its use would probably have improved our results for the most severe injuries. There was also variation in postoperative management in our trauma center, with three different orthopaedic consultants and several residents managing patients at any given time. Further, the lack of fracture type homogeneity in the three treatment groups influenced the PCS and MCS scores values so as to make comparison difficult, without apparent statistical significance. Another possible bias is severity of injury and subsequent choice of fixation: in particular, the use of MIPO for less challenging cases and subsequent good results. The use of EF in the two-step technique for the more complex soft tissue injuries could explain the high infection rate we report, including pin-tract infections, even if they were resolved in all cases by antibiotic therapy. Another potential limitation is that we did not collect the education levels and jobs of our patients, which is reportedly associated with better ankle score when it is high, in particular for white-collar jobs [34]. In addition, the few EF readjustments performed during the patients' outcome activities were not always reported in the clinical notes. However, in comparison to other retrospective recent studies [9, 3840], our report presents a large sample size (94 patients), taking into account the relatively low incidence of pilon fractures ( $1 \%$ of all lower extremity fractures); it is also one of the largest monocenter cohorts studied, with only three treating surgeons. Another strength of this study is the good quality of data reported from our hospital database, recorded according to our standard aftercare algorithm, which were collected by an independent investigator. The analysis of the clinical and radiographic outcomes was carried out separately by two other researchers and finally analyzed by an independent statistician, blinded to the type of technique treatment in order to reduce bias. Further, the medium-longterm follow-up period allowed the assessment of different functional aspects, as convalescence tends to be long. To perform a comparison of the various possibilities of treatment for the same type of fracture, a prospective trial with a strict standardized protocol, validated functional outcome measurements and a control group would yield stronger evidence.

\section{Conclusion}

Although the documented complications are mostly minor with percentages comparable to those described in the available literature, this case series study reports satisfactory results using the three different techniques for the treatment of articular pilon fractures. In particular, the radiographic outcomes were inversely proportional to the fracture comminutions, statistically different between internal and external osteosynthesis, but comparable between ORIF and MIPO techniques. On the other hand, the clinical outcomes were closely related to the soft tissue conditions and the anatomical reconstruction of the joint. In summary, as can be expected, our findings show that the most severe injuries and the worst radiographic results were related to the worst functional and patient reported outcomes. However, the proper surgical treatment must be carefully chosen for these challenging fractures.

\section{Ethical Approval}

The patients received a thorough explanation of this study and gave their oral and written informed consent to be included in this analysis as well as for publication of these cases, anonymous data, and pictures.

\section{Conflicts of Interest}

The authors declare that they have no conflicts of interest related to the publication of this manuscript.

\section{Authors' Contributions}

Carlo Biz and Silvano Pierluigi Sperotto contributed to study concept and design as well as drafting the paper; Filippo Marzotto and Marco Zamperetti contributed to data collection and statistical analysis; Diego Carniel and Filippo Marzotto contributed to analysis and interpretation of data; Pietro Ruggieri, Andrea Angelini, and Claudio Iacobellis contributed to study concept and final approval of the version to be published.

\section{Acknowledgments}

The authors acknowledge Professor A. Ch. Frigo for her assistance with the statistical analysis.

\section{References}

[1] D. Volgas, J. G. DeVries, and J. P. Stannard, "Short-term Financial Outcomes of Pilon Fractures," Journal of Foot and Ankle Surgery, vol. 49, no. 1, pp. 47-51, 2010.

[2] M. Blauth, L. Bastian, C. Krettek, C. Knop, and S. Evans, "Surgical options for the treatment of severe tibial pilon fractures: A study of three techniques," Journal of Orthopaedic Trauma, vol. 15, no. 3, pp. 153-160, 2001.

[3] G. M. Calori, L. Tagliabue, E. Mazza et al., "Tibial pilon fractures: Which method of treatment?" Injury, vol. 41, no. 11, pp. 1183-1190, 2010. 
[4] J. Scolaro and J. Ahn, "Pilon fractures," Clinical Orthopaedics and Related Research, vol. 469, no. 2, pp. 621-623, 2011.

[5] M. Othman and P. Strzelczyk, "Results of conservative treatment of "pilon" fractures," Ortopedia, Traumatologia, Rehabilitacja, vol. 5, pp. 787-794, 2003.

[6] T. W. Lau, F. Leung, C. F. Chan, and S. P. Chow, "Wound complication of minimally invasive plate osteosynthesis in distal tibia fractures," International Orthopaedics, vol. 32, no. 5, pp. 697-703, 2008.

[7] V. Pai, G. Coulter, and V. Pai, "Minimally invasive plate fixation of the tibia," International Orthopaedics, vol. 31, no. 4, pp. 491496, 2007.

[8] T. P. Rüedi and M. Allgöwer, "The operative treatment of intra-articular fractures of the lower end of the tibia," Clinical Orthopaedics and Related Research, vol. 138, pp. 105-110, 1979.

[9] D. Vidović, A. Matejčić, M. Ivica, D. Jurišić, E. Elabjer, and B. Bakota, "Minimally-invasive plate osteosynthesis in distal tibial fractures: Results and complications," Injury, vol. 46, pp. S96S99, 2015.

[10] I. S. Tarkin, M. P. Clare, A. Marcantonio, and H. C. Pape, "An update on the management of high-energy pilon fractures," Injury, vol. 39, no. 2, pp. 142-154, 2008.

[11] AO Foundation, Switzerland Müller AO Classification of Fractures - Long Bones 2010, https://www.aofoundation.org/.

[12] R. B. Gustilo and J. T. Anderson, "Prevention of infection in the treatment of one thousand and twenty five open fractures of long bones: retrospective and prospective analyses," The Journal of Bone \& Joint Surgery, vol. 58, no. 4, pp. 453-458, 1976.

[13] D. N. Ovadia and R. K. Beals, "Fractures of the tibial plafond," The Journal of Bone \& Joint Surgery, vol. 68, no. 4, pp. 543-551, 1986.

[14] H. B. Kitaoka, I. J. Alexander, R. S. Adelaar, J. A. Nunley, M. S. Myerson, and M. Sanders, "Clinical rating systems for the ankle-hindfoot, midfoot, hallux, and lesser toes," Foot \& Ankle International, vol. 15, no. 7, pp. 349-353, 1994.

[15] https://campaign.optum.com/optum-outcomes/what-we-do/ health-surveys/sf-36v2-health-survey.

[16] G. Apolone, P. Mosconi, L. Quattrociocchi, E. Gianicolo, N. Groth, and E. John, "Questionario sullo stato di salute SF-12 Versione italiana," Versione IRFMN, 2005.

[17] S. Boraiah, T. J. Kemp, A. Erwteman, P. A. Lucas, and D. E. Asprinio, "Outcome following open reduction and internal fixation of open pilon fractures," The Journal of Bone \& Joint Surgery, vol. 92, no. 2, pp. 346-352, 2010.

[18] T. Lee, N. M. Blitz, and S. M. Rush, "Percutaneous Contoured Locking Plate Fixation of the Pilon Fracture: Surgical Technique," Journal of Foot and Ankle Surgery, vol. 47, no. 6, pp. 598602, 2008.

[19] C. Wang, Y. Li, L. Huang, and M. Wang, "Comparison of twostaged ORIF and limited internal fixation with external fixator for closed tibial plafond fractures," Archives of Orthopaedic and Trauma Surgery, vol. 130, no. 10, pp. 1289-1297, 2010.

[20] A. N. Pollak, M. L. McCarthy, R. S. Bess, J. Agel, and M. F. Swiontkowski, "Outcomes after treatment of high-energy tibial plafond fractures," The Journal of Bone \& Joint Surgery, vol. 85, no. 10, pp. 1893-1900, 2003.

[21] J. L. Marsh, D. P. Weigel, and D. R. Dirschl, “Tibial plafond fractures. How do these ankles function over time?" The Journal of Bone \& Joint Surgery, vol. 85, no. 2, pp. 287-295, 2003.

[22] J. Conroy, M. Agarwal, P. V. Giannoudis, and S. J. E. Matthews, "Early internal fixation and soft tissue cover of severe open tibial pilon fractures," International Orthopaedics, vol. 27, no. 6, pp. 343-347, 2003.

[23] C. Bastias, H. Henríquez, M. Pellegrini et al., "Are locking plates better than non-locking plates for treating distal tibial fractures?" Journal of Foot and Ankle Surgery, vol. 20, no. 2, pp. 115-119, 2014.

[24] D. Gülabi, Ö. Toprak, C. Şen, C. C. Avci, E. Bilen, and F. Sağlam, "The mid-term results of treatment for tibial pilon fractures," Ulusal Travma ve Acil Cerrahi Dergisi, vol. 18, no. 5, pp. 429435, 2012.

[25] W. Cheng, Y. Li, and W. Manyi, "Comparison study of two surgical options for distal tibia fracture - Minimally invasive plate osteosynthesis vs. open reduction and internal fixation," International Orthopaedics, vol. 35, no. 5, pp. 737-742, 2011.

[26] F. Dujardin, H. Abdulmutalib, and A. C. Tobenas, "Total fractures of the tibial pilon," Orthopaedics \& Traumatology: Surgery \& Research, vol. 100, no. 1 S, pp. S65-S74, 2014.

[27] Ó. Fernández-Hernández, I. Álvarez-Posadas, J. BetegónNicolás, J. González-Fernández, and S. Sánchez-Herráez, "Fractures of the tibial pilon. Long-term functional results," Revista Española de Cirugía Ortopédica y Traumatología (English Edition), vol. 52, no. 3, pp. 152-160, 2008.

[28] R. Elsoe, S. Kold, P. Larsen, and J. Petruskevicius, "A prospective observational study of 56 patients treated with ring fixator after a complex tibial fracture," Strategies in Trauma and Limb Reconstruction, vol. 12, no. 1, pp. 35-44, 2017.

[29] T. Ramos, J. Karlsson, B. I. Eriksson, and L. Nistor, “Treatment of distal tibial fractures with the Ilizarov external fixator - a prospective observational study in 39 consecutive patients," BMC Musculoskeletal Disorders, vol. 14, no. 1, 2013.

[30] B. D. Crist, M. Khazzam, Y. M. Murtha, and G. J. Della Rocca, "pilon Fractures: Advances in Surgical Management," American Academy of Orthopaedic Surgeon, vol. 19, no. 10, pp. 612-622, 2011.

[31] A. Korkmaz, M. Çiftdemir, M. Özcan, C. Çopuroğlu, and K. Saridoğan, "The analysis of the variables, affecting outcome in surgically treated tibia pilon fractured patients," Injury, vol. 44, no. 10, pp. 1270-1274, 2013.

[32] J. A. Lewis, H. Vint, and I. Pallister, "Pilot study assessing functional outcome of tibial pilon fractures using the VSTORM method," Injury, vol. 44, no. 8, pp. 1112-1116, 2013.

[33] T. A. DeCoster, M. C. Willis, J. L. Marsh et al., "Rank order analysis of tibial plafond fractures: Does injury or reduction predict outcome?” Foot \& Ankle International, vol. 20, no. 1, pp. 44-49, 1999.

[34] T. M. Williams, J. V. Nepola, T. A. DeCoster, S. R. Hurwitz, D. R. Dirschl, and J. L. Marsh, "Factors affecting outcome in tibial plafond fractures," Clinical Orthopaedics and Related Research, no. 423, pp. 93-98, 2004.

[35] L. J. Bonato, E. R. Edwards, C. M. Gosling et al., "Patient reported health related quality of life early outcomes at 12 months after surgically managed tibial plafond fracture," Injury, vol. 48, no. 4, pp. 946-953, 2017.

[36] J. L. Marsh, T. McKinley, D. Dirschl et al., "The sequential recovery of health status after tibial plafond fractures," Journal of Orthopaedic Trauma, vol. 24, no. 8, pp. 499-504, 2010.

[37] J. T. Watson, B. R. Moed, D. E. Karges, and K. E. Cramer, "Pilon fractures: Treatment protocol based on severity of soft tissue injury," Clinical Orthopaedics and Related Research, no. 375, pp. 78-90, 2000. 
[38] M. Leonard, P. Magill, and G. Khayyat, "Minimally-invasive treatment of high velocity intra-articular fractures of the distal tibia," International Orthopaedics, vol. 33, no. 4, pp. 1149-1153, 2009.

[39] P. A. McCann, M. Jackson, S. T. Mitchell, and R. M. Atkins, "Complications of definitive open reduction and internal fixation of pilon fractures of the distal tibia," International Orthopaedics, vol. 35, no. 3, pp. 413-418, 2011.

[40] F. Lavini, C. Dall'Oca, S. Mezzari et al., "Temporary bridging external fixation in distal tibial fracture," Injury, vol. 45, no. 6, pp. S58-S63, 2014. 


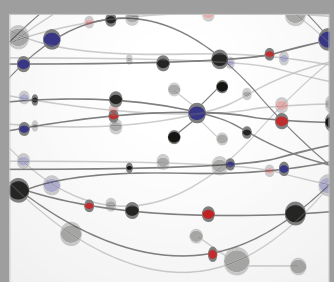

The Scientific World Journal
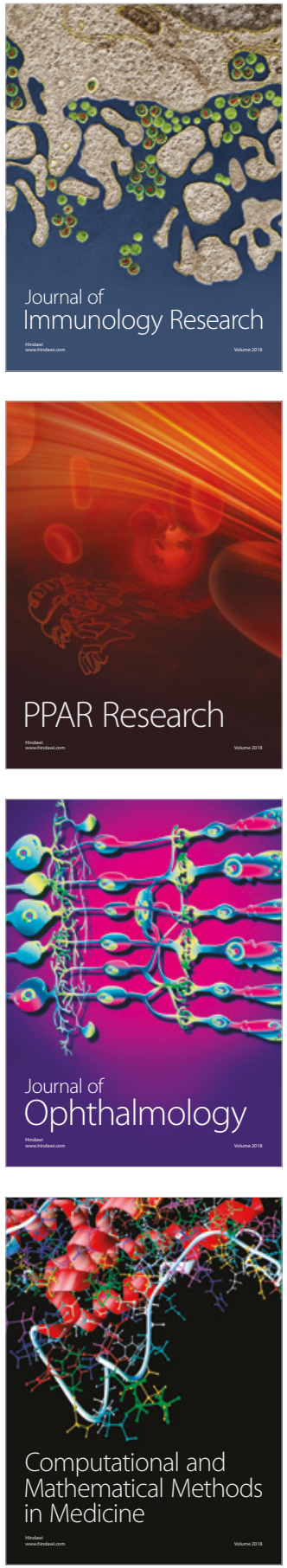

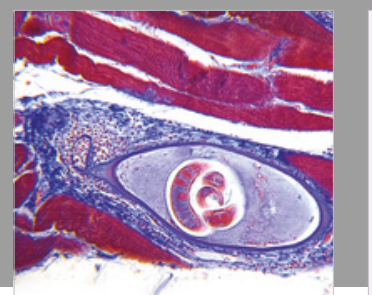

Gastroenterology Research and Practice

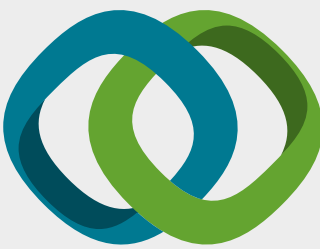

\section{Hindawi}

Submit your manuscripts at

www.hindawi.com
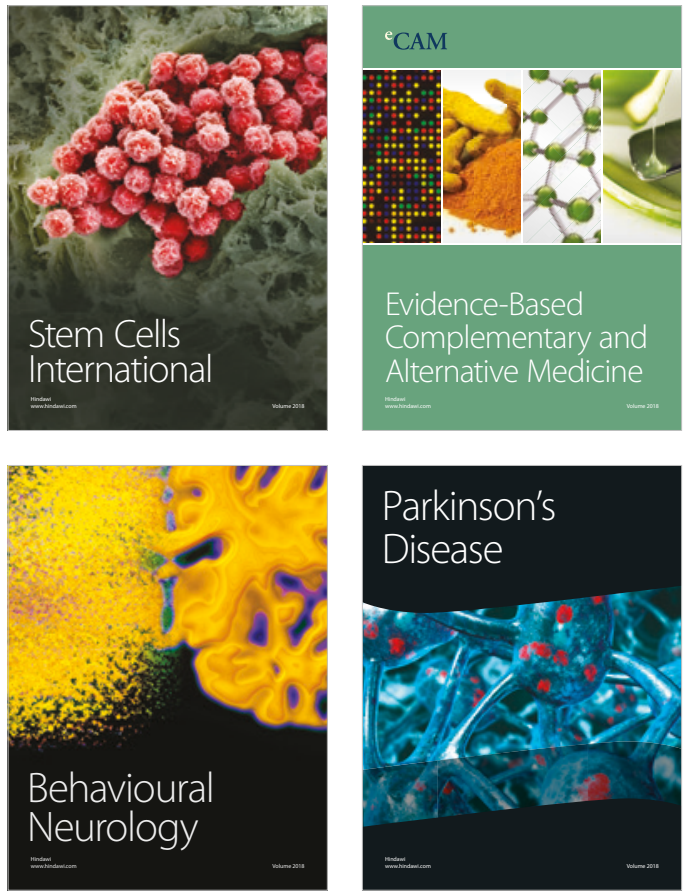

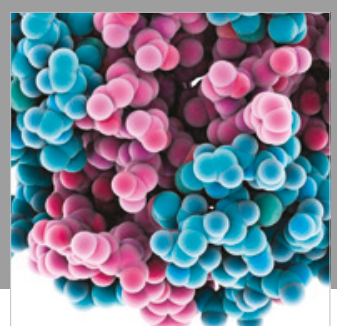

ournal of

Diabetes Research

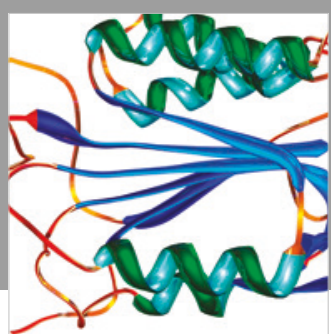

Disease Markers
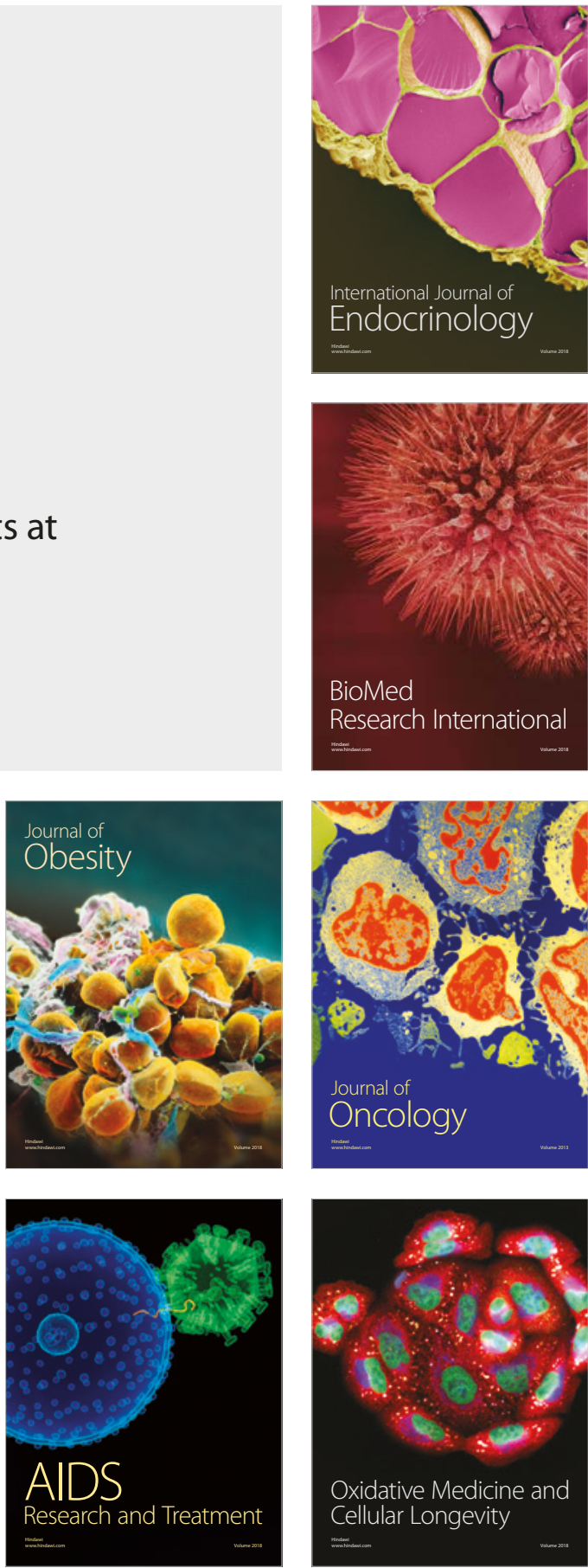